\title{
THE STORMWATER DRAIN SYSTEM AS A POLLUTION VECTOR OF THE SEASHORE IN FORTALEZA (CEARÁ STATE, BRAZIL)
}

\author{
Regine H.S.F. Vieira ${ }^{1 *}$; Karla M. Catter²; Silvana Saker-Sampaio ${ }^{2}$; Dália P. Rodrigues ${ }^{3}$; Grace N.D. Theophilo ; \\ Antonio A. Fonteles-Filho ${ }^{4}$
}

${ }^{1}$ Instituto de Ciências do Mar, Universidade Federal do Ceará, Fortaleza, CE, Brasil; ${ }^{2}$ Departamento de Engenharia de Pesca, Universidade Federal do Ceará, Fortaleza, CE, Brasil; ${ }^{3}$ Fundação Oswaldo Cruz, Rio de Janeiro, RJ, Brasil; ${ }^{4}$ Fellow-Researcher of the Brazilian Science Foundation (CNPq) at Instituto de Ciências do Mar, Universidade Federal do Ceará, Fortaleza, CE, Brasil.

Submitted: January 08, 2002; Returned to authors for corrections: June 12, 2002; Approved: December 05, 2002

\begin{abstract}
The aim of this study was to make a diagnosis of coastal pollution through bacteriological analysis of water taken from stormwater drain systems and the nearby seashore. The results were submitted to statistical analysis as to differences in the Most Probable Number (MPN) of fecal coliform (FC) found between the stormwater drain systems and adjacent seashore locations both at low and high tides. The main conclusions were: (a) most water samples collected from the stormwater systems presented MPN values for FC above 1,000 per $100 \mathrm{ml}$; (b) only $20 \%$ of the samples from the adjacent seashore presented MPN values for FC above 1,000 per $100 \mathrm{ml}$, a fact which may be explained by the distance between the drain system outlets and the actual seashore; (c) FC/100 ml values were invariably higher in the stormwater drain systems than in seawater; (d) out of the 180 strains isolated, 118 were Escherichia coli; (e) the highest in-sewer pollution rate was found at the sampling location in front of Imperial Othon Palace Hotel (IO-SEW), characterized by the presence of an everlasting puddle, while the most polluted seawater sample was taken in front of Statue of Iracema (SI-SEA); (g) the high tide regime enhances the chance of pollution of the coastal zone by fecal coliforms; (h) the high pollution indices by fecal coliforms can only be accounted for by the existence of illegal sewage pipelines connected to the stormwater drain systems.
\end{abstract}

Key words: stormwater drain system, fecal coliforms, marine pollution

\section{INTRODUCTION}

The drainage system of the urban areas provides an outlet for the rainwater from streets and buildings. The quality of this runoff water depends on the cleanliness, spatial and temporal distribution and intensity of rainfalls, time of the year and urban space usage (13).

The stormwater would run through the drain system without becoming contaminated with fecal matter if it were not for the wastewater which is illegally fed into it in a number of places. Also, according to Arnold and Gibbons, (1) a recognized major source of microbial contamination to surface waters is the stormwater runoff, which accounts for a significant share of pollution in coastal waters as well as in urbanized areas where rain falling on impervious surfaces is unable to infiltrate into surface soils and runs off into stormwater control systems. Fecal material and other waste that are present on impervious surfaces, including pavement, roofs, sidewalks, patios, bedrock outcrops and compact soil are washed off and carried along with the rainfall runoff into surface waters. In Wisconsin, the highest levels of Escherichia coli in runoff were detected in residential and commercial areas, less importance being attached to roof, parking lot, driveway and sidewalk sources (2). On the other hand, as it is, public health and, especially the health of beachgoers, are severely threatened by the disposal of raw sewage to the stormwater which flows out onto the seashore. Children, elderly people and those with relatively lower resistance to infection by bacteria, virus and protozoans are at a special risk (15).

* Corresponding author. Mailing address: Av. da Abolição, 3207. 60165-081, Fortaleza, CE, Brasil. Fax (+5585) 242-8355. E-mail: regine@labomar.ufc.br 
The aim of this study was to monitor the bacteriological condition of the water of three stormwater drain systems and of the adjacent marine area where they discharge along the eastern seashore of Fortaleza city, Ceará State, Brazil.

\section{MATERIALS AND METHODS}

\section{Collection Sites}

Bacteriological analyses were performed on 45 water samples from three stormwater drain systems (SEW) located along the eastern seashore of Fortaleza, CE, Brazil, (Fig. 1) and 45 water samples from three adjacent seashore locations (SEA), during high and low tides. All 90 samples were collected in the period from September, 2000 through March, 2001.

The exact sampling locations were in front of Esplanada Hotel (EH-SEW and EH-SEA), Imperial Othon Palace Hotel (IOSEW and IO-SEA), and Statue of Iracema (SI-SEW and SI-SEA).

Each sample consisted of $500 \mathrm{ml}$ of water drawn from either the drain system or the seashore, stored in sterilized ambercolored vials and taken to a nearby laboratory for immediate processing. All sampling activities took place in the morning.

\section{Coliforms enumeration}

The Most Probable Numbers (MPN) of total coliform (TC) and fecal coliforms (FC) were determined using the multiple tube method (11), with the aid of Hoskins' table (8).

\section{Escherichia coli isolation}

Positive EC broth tubes were sheaked on plates with methylene blues eosine agar-EMB and two colonies per sample were isolated for the identification of $E$. coli (11).

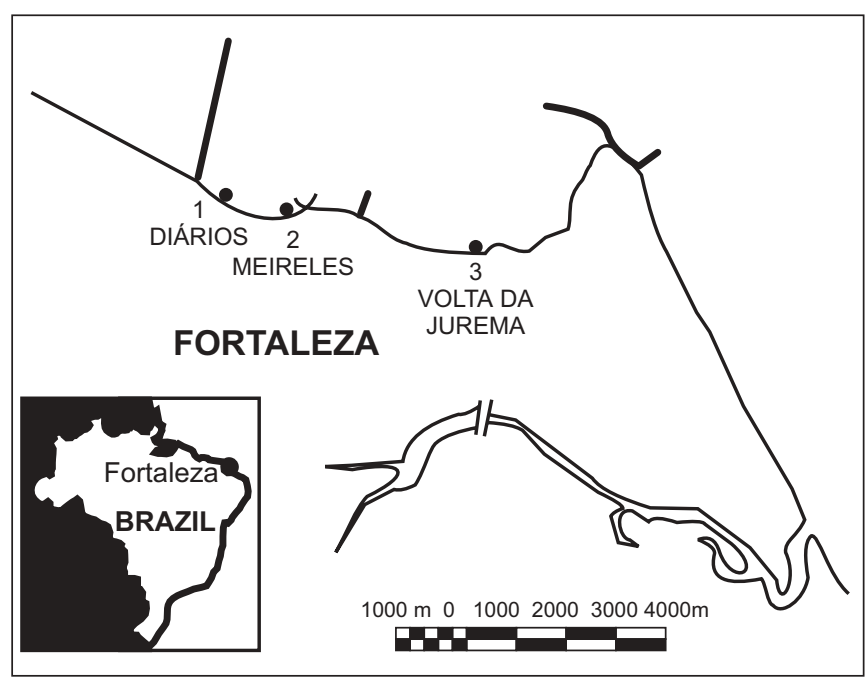

Figure 1. Map of eastern Fortaleza county, indicating the sampling sites of stormwater drain systems: 1 - Esplanada Hotel; 2 - Imperial Othon Palace Hotel; 3 - Statue of Iracema.
The identified E. coli strains were serum-typed through agglutination with specific sera in order to verify the presence of enteropathogenic groups (6).

\section{Statistical analysis}

The MPN values for FC transformed in logarithms, found at sampling locations EH-SEW, EH-SEA, IO-SEW, IO-SEA, SI-SEW and SI-SEA, were submitted to Unifactorial ANOVA in order to evaluate to what extent they are influenced by the tide regime. In the case of null hypothesis rejection, the mean MPN values were compared through the Tukey test. In both tests the $a=$ 0.05 significance level was utilized.

\section{Rainfall index}

The rainfall indices for all 24-hour periods preceding the sampling activities were provided by FUNCEME (Ceará State Meteorological Foundation).

\section{RESULTS AND DISCUSSION}

Table 1 shows the MPN values for FC in samples from the three stormwater drain systems and adjacent seashore locations. These values are also displayed in Figs. 2 to 4 . Nine samples $(63.0 \%)$ from the EH-SEW location rendered FC values above

Table 1. Sample and average values of the Most Probable Number (MPN) of fecal coliforms (FC) on water samples in front of Esplanada Hotel (EH), Imperial Othon Palace Hotel (IO) and Statue of Iracema (SI) from stormwater drain systems (SEW) and adjacent seashore (SEA), during high and low tides.

\begin{tabular}{rrrrrr}
\hline EH-SEW EH-SEA & IO-SEW & IO-SEA & SI-SEW & SI-SEA \\
\hline \multicolumn{7}{c}{ High Tides } \\
\hline 43,000 & $<300$ & 43,000 & $<300$ & 4,300 & 400 \\
- & $<300$ & 4,300 & $<300$ & 23,000 & 400 \\
400 & 400 & 43,000 & $<300$ & 4,300 & 400 \\
7,500 & $<300$ & 23,000 & $<300$ & 9,300 & 2,300 \\
23,000 & $<300$ & - & $<300$ & 43,000 & $<300$ \\
210,000 & 4,300 & $>1,100,000$ & 2,300 & $>1,100,000$ & 21,000 \\
2,300 & $<300$ & 460,000 & $<300$ & 210,000 & $<300$ \\
15,000 & 900 & 28,000 & $<300$ & 150,000 & 21,000 \\
400 & $<300$ & 240,000 & 4,000 & 23,000 & $<300$ \\
\hline 37,700 & 822 & 242,663 & 933 & 174,100 & 5,156 \\
\hline \multicolumn{6}{c}{ Low Tides } \\
\hline 15,000 & 4,300 & 210,000 & 7,500 & 15,000 & 43,000 \\
$<300$ & $<300$ & 460,000 & $<300$ & 23,000 & 4,300 \\
$<300$ & $<300$ & 93,000 & $<300$ & 43,000 & $<300$ \\
9,000 & $<300$ & 15,000 & $<300$ & 2,300 & 9,300 \\
23,000 & 400 & 240,000 & $<300$ & 240,000 & 460,000 \\
400 & $<300$ & 9,300 & $<300$ & 15,000 & $<300$ \\
\hline 8,000 & 983 & 171,217 & 1,500 & 56,383 & 86,200 \\
\hline \multicolumn{7}{c}{}
\end{tabular}




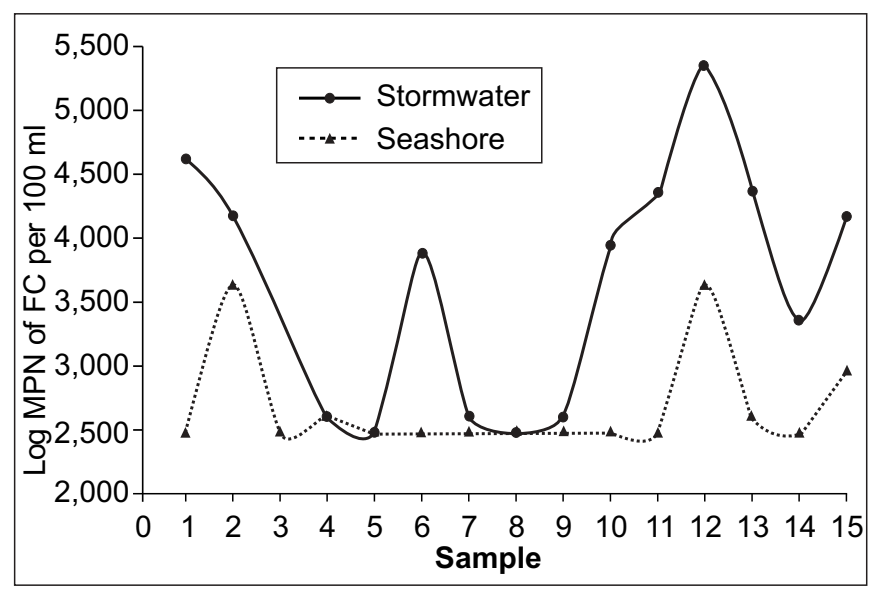

Figure 2. Sample variation of the Most Probable Number (MPN) of fecal coliforms (FC) per $100 \mathrm{ml}$ of sample water from the EHSEW stormwater drain system and its adjacent seashore (EHSEA).

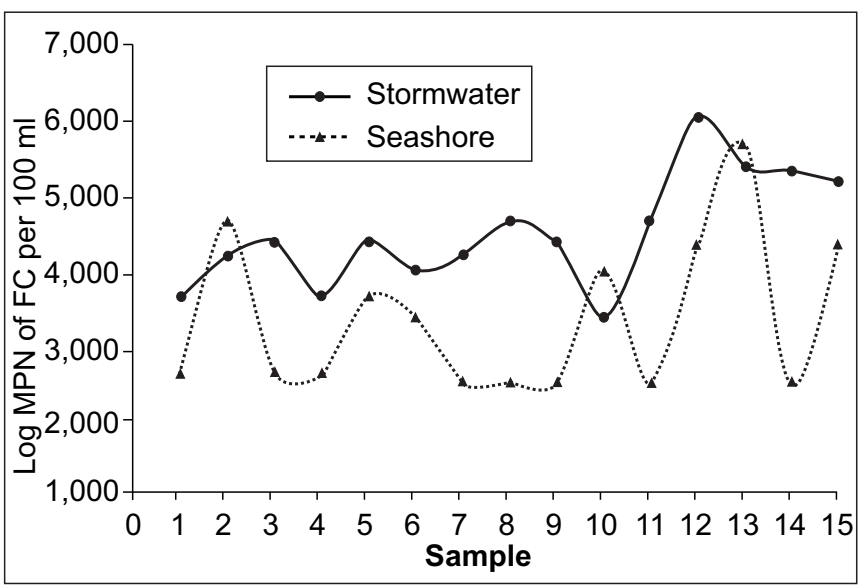

Figure 3. Sample variation of the Most Probable Number (MPN) of fecal coliforms (FC) per $100 \mathrm{ml}$ of sample water from the IOSEW stormwater drain system and its adjacent seashore (IOSEA).

1,000 per $100 \mathrm{ml}$. The EH-SEW stormwater drain system runs from Tenente Benévolo Street to the end of Barão de Studart Avenue and discharges next to Esplanada Hotel. Two (13.3\%) out of fifteen samples taken from the seawater in front of Esplanada Hotel (EH-SEA) presented FC values above 1,000 per $100 \mathrm{ml}$. Despite the stench coming from the stormwater drain systems on the eastern seashore of Fortaleza, many beachgoers and other visitors, mostly foreign tourists staying at the hotels along the waterfront, are seen lounging in the area. Many of these visitors are unaware of the health risks to which they are thus exposed.

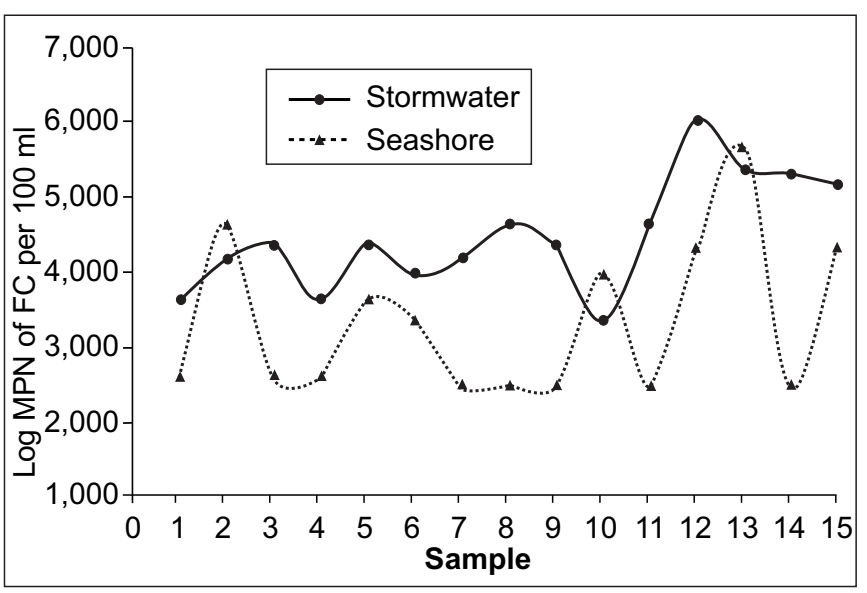

Figure 4. Sample variation of the Most Probable Number (MPN) of fecal coliforms (FC) per $100 \mathrm{ml}$ of sample water from the SISEW stormwater drain system and its adjacent seashore (SISEA).

Water taken from the stormwater drain system of Imperial Othon Palace Hotel (IO-SEW), in front of whose outlet a large, muddy puddle of wastewater may be seen on the sand, displayed MPN values for FC above 1,000 per $100 \mathrm{ml}$ in $100 \%$ of the samples.

Only three (20\%) of the IO-SEA water samples (from the sea adjacent to the IO-SEW stormwater drain system) presented MPN values for FC above 1,000 per $100 \mathrm{ml}$, and thus it is surprising that the seawater is not more polluted at such a location. In fact, the IO-SEW stormwater drain system does not discharge directly into the sea but rather it delivers its waters into a large puddle in a sand depression at some distance from the water's edge. If examined, the sand at this location may turn out to be as polluted as the water collected from the drain system itself (Table 1).

The pathogenic bacteria present in the sand on this beach may cause outbreaks of gastroenteritis, salmonellosis, hepatitis, viral diseases, dermatitis and mycosis which in the summer have mostly been associated with polluted seawater (12). However, while the quality control of seaside areas usually includes a microbiological examination of the bathing water, it very rarely considers verifying the possibility of sand pollution (15).

The SI-SEW stormwater drain system is represented by three different systems, namely Maceió Creek, General Hospital and Santos Dumont Avenue, whose discharges are channeled through Maceió Creek's mouth. All 15 water samples (100\%) collected there presented MPN values for FC above 1,000 per $100 \mathrm{ml}$. There is decidedly a foul smell in the vicinity of the stormwater drain system outlet, a fact which in itself, and according to CONAMA (3), justifies rating the beach improper for bathing. Seven (46.6\%) of the water samples from its adjacent seawater (SI-SEA) presented MPN values for FC above 1,000 per $100 \mathrm{ml}$ (Table 1$)$. 
Terrestrial human activity is generally believed to be able to reduce the carrying capacity of a number of marine ecosystems. The natural coastal discharge of rivers may add to marine pollution due to the contribution of runoff water containing sewage and toxic substances (18). Brazilian big cities located along the country's coastline, such as Rio de Janeiro, Salvador, Fortaleza, Recife, Belém and Florianópolis are home to over 18 million people (4) and, thus, are known to have been contributing to outstanding indices of marine pollution over the past few years.

The main source of contamination of the Brazilian beaches consists of fecal microorganisms carried along with rain water runoff and other drainage outlets adjacent to the seashore, since domestic and/or industrial wastewater sewers are often illegally connected to stormwater drain systems. Another important source of pollution is the rubbish washed off the city streets during heavy rainfalls (16). Few studies conducted thorough enough investigations to rule out human sources of contamination, but recent investigations have shown cross connections, leaky sewage pipes and other infrastructure-related problems to be a significant cause of contaminant loading, especially in urban and residential areas, along with animal feces (9). Only now the ability to differentiate between animal and human microbial contamination is becoming developed. Thus, the question of the how public health is related to stormwater runoff is complicated by the incompleteness of most investigations on this subject and the inability to differentiate between human and non-human sources of contaminants that are present in surface waters.

The water samples collected show that MPN values for FC are invariably higher in the stormwater drain systems than in their adjacent seashore water. Hagler and Hagler (7) state that sea water is toxic to most enteric bacteria but in the present study we have limited the discussion to the data obtained for fecal coliform, because this is the type of microorganism referred to in the CONAMA Act 274/2000.

Out of 180 strains isolated from 15 samples, 118 were $E$. coli. The organisms Enterobacter aerogenes and Citrobacter sp. were also isolated. The presence of $E$. coli in the coastal waters of Fortaleza represents a serious health risk to both visitors and city dwellers, especially because certain strains are known to bring about gastrointestinal disorders in children and adults (16). It also suggests environmental contamination by other bacteria of fecal origin such as Salmonella, Shigella and Vibrio cholerae, which are very often pathogenic to human beings (17).

Samples numbered 6 (SI-SEW) and 10 (EH-SEW) were found to contain E. coli of serogroup $\mathrm{O}_{25}$, which may be ETEC. ETEC produces thermolabile (LT) and/or thermostable (ST) enterotoxins and has been shown to be a frequent cause of diarrhea in developing countries, especially among young children (14).
According to the ANOVA results, the mean MPN values, independent of the sampling site, were higher during high tide, with statistical significance on both the stormwater drain systems $(\mathrm{F}=3.659 ; \mathrm{P}<0.05)$ and the adjacent seashore waters $(\mathrm{F}=2.746 ; \mathrm{P}<0.05)$. As for individual comparisons between individual sampling means, the Tukey test indicated a statistically-significant difference between the following sites: (a) EH-SEW location at low tide and IO-SEW location at high tide $(\mathrm{HSD}=1.508 ; \mathrm{P}<0.05)$ and low tide $(\mathrm{HSD}=1.572 ; \mathrm{P}<0.05)$; (b) EH-SEA location at high tide and SI-SEA location (which includes Maceió Creek) at low tide (HSD = 1.136; P <0.05); (c) IO-SEA location at high tide and the SI-SEA location at low tide $(\mathrm{HSD}=1.118 ; \mathrm{P}<0.05)$.

The only rainfall observed during the study period, namely $1.2 \mathrm{~mm}$ occurred during the last sampling of March. However, although no rain fell on any other sampling day, wastewater puddles with very high FC indices could be seen at the outlets of the stormwater drain systems. Samples numbered 3 (EHSEW) and 11 (IO-SEW) could not be analyzed because the sampling location had dried out on the occasion. However, this fact is by no means significant when it is taken into account that the remaining 43 water samples were successfully collected and that they all presented relatively high MPN values for FC (Table 1).

The findings of this study suggest that besides the load of contaminants originated from used water by homes and hospitals, and feces from stray animals, the high pollution indices can only be accounted for by the contamination of beaches with fecal coliform from illegally-connected waster water sewers (5), even though the densely-populated Beira-Mar district has at their disposal a network of working sewage pipelines. Although a beach clean-up program by Ceará State's Department for the Environment (SEMACE) was known to have sealed off over 60 illegal connections to the stormwater drain system, the water quality of the adjacent beaches has not improved perceptibly because they may somehow be still contaminated by sewage, therefore continuing to pose serious health hazards to those who visit or dwell along the eastern seashore of Fortaleza. According to Jones and Bryant (10), studies based on identification of Escherichia coli through ribotyping could help focusing resources to mitigate the most significant pollution sources on stormwaters.

\section{RESUMO}

\section{Sistema de galerias pluviais como vetor poluente da zona costeira de Fortaleza, Ceará, Brasil}

O objetivo deste trabalho foi realizar o diagnóstico da poluição costeira, através da análise bacteriológica da água de galerias pluviais e da zona marinha adjacente. Entre setembro de 2000 e março de 2001 foram obtidas 90 amostras, sendo 45 
nas galerias e 45 na adjacente zona marinha, localizadas em frente aos seguintes pontos de coleta: Esplanada Hotel, Imperial Othon Palace e Estátua de Iracema. Os resultados foram apresentados como o Número Mais Provável (NMP) de coliformes fecais por $100 \mathrm{ml}(\mathrm{CF} / 100 \mathrm{ml})$, e submetidos a comparação estatística nos regimes de preamar e baixamar por Análise de Variância e Teste de Tukey. As conclusões são: (a) a maior parte das amostras de água coletadas nas galerias apresentou valores de NPM de CF/100 ml superiores a 1.000; (b) a zona marinha adjacente apresentou apenas $20 \%$ das amostras com NPM de CF/100 ml maior do que 1.000 , fato que pode estar relacionado com a distância das galerias à praia; (c) as galerias apresentaram NMP de $\mathrm{CF} / 100 \mathrm{ml}$ sempre mais altos que a zona marinha; (d) das 180 cepas isoladas, 118 eram $E$. coli; (e) os maiores índices de poluição por $\mathrm{CF}$ em galerias ocorreram em frente ao Imperial Othon Palace e, na zona marinha adjacente, em frente à Estátua de Iracema; (f) o regime de preamar contribui para o aumento da poluição da zona costeira por coliformes fecais; (g) os elevados índices de poluição por coliformes fecais só podem ser explicados pela existência de esgotos ilegais conectados às galerias pluviais.

Palavras-chave: galerias pluviais, coliformes fecais, poluição marinha.

\section{REFERENCES}

1. Arnold, C.L.; Gibbons, C.J. Impervious surface coverage: the emergence of a key environmental indicator. Amer. Planning. Assn. J., 62: 243-258, 1996.

2. Bannerman, R.T.; Owens, D.W.; Dodds, R.B.; Hornewer, N.J. Sources of pollutans in Wiscosin stormwater. Wat. Sci. Tech., 28: 241-259, 1993.

3. Brasil. Conselho Nacional do Meio Ambiente. Resolução CONAMA $\mathrm{N}^{\circ} 274$, de 29 de novembro de 2000. SEMA, Brasília, 2000.
4. Brasil. Comissão Nacional Independente dos Oceanos - Brasil e o mar no Século XXI: Relatório aos tomadores de decisão do país. CNID, Rio de Janeiro, 1998, p. 408.

5. Carneiro, D.M.G.; Marques, K.M.M.O.; Soares, J.B. Avaliação da balneabilidade das praias do litoral de Fortaleza. SEMACE, Fortaleza, 1991, 67p.

6. Ewing, W.H. Differentiation of Enterobacteriaceae by biochemical reactions. In: Edward, P.R,; Ewing, W.H. (eds). Edward and Ewing's Identification of Enterobacteriaceae. $4^{\text {th }}$ ed., Elsevier, New York , 1986, 536p.

7. Hagler, A.N.; Hagler, L.C.S.M. Indicadores microbiológicos de qualidade sanitária. In: Roitman, I.; Travassos, L.R.; Azevedo, J.L. (eds) Tratado de Microbiologia. Manole, São Paulo. 1988, p. 8896.

8. Hoskins, J.K. The most probable numbers of Escherichia coli in water analysis. J. Am. Water Works Ass., 25(6): 867-877, 1933.

9. Jones, S.H. Public health significance of stormwater-borne microorganisms. A Final Report to the New Hampshire department of environmental services. Durham, 1999, 41p.

10. Jones, S.H.; Bryant,T. Ribotyping to identify source species of Escherichia coli in two Vermont Water-sheds. American Society for Microbiology $102^{\text {nd }}$ General Meeting, Salt Lake, 2002.p.438.

11. Mehlman, I.J.; Andrews, W.H.; Wentz, B.A. Coliform bacteria In: Bacteriological Analytical Manual, $6^{\text {th }}$ ed., AOAC, Arlington 1984, p. 5.01-5.07.

12. Mendes, B.; Nascimento, M.J.; Oliveira, J.S. Preliminary characterisation and proposal of microbiological quality standard of sand beaches. Wat. Sci. Tech., 27(3-4): 453-356, 1993.

13. Mota, J.C.; Tucci, C.E.M. Simulation of the urbanization effect in flow. J. Hydrol. Sci., 29(2): 131-147, 1994.

14. Navaro, F.; Kaper, J.B. Diarrheagenic Escherichia coli. Clin. Microbiol. Rev., 11: 142-201, 1998.

15. São Paulo. Secretaria de Estado do Meio Ambiente. Balneabilidade das praias paulistas. CETESB, São Paulo, 1998, 204p. (Relatórios ambientais).

16. Soares, J.B.; Maia, A.C.F. Água, microbiologia e tratamento. UFC, Fortaleza, 1999, p.62-179.

17. Vieira, R.H.S.F.; Evangelista, N.S.S.; Rodrigues, D.P. Colimetria das águas marinhas de Fortaleza e detecção de cepas de Escherichia coli enteroinvasora (EIEC) e enteropatogênica clássica (EPEC). Arq. Ciên. Mar, 30: 27-31, 1996.

18. Vieira, R.H.S.F. Poluição microbiológica de algumas praias brasileiras. Arq. Ciên. Mar, 33: 77-84, 2000. 